Seminário de Pesquisa

Programa de Pós-Graduação

Design FAU USP

\title{
Cidades inteligentes, smart cities: uma revisão bibliográfica sistemática
}

\author{
André Deak Alonso, Giselle Beiguelman
}

\author{
smart cities; cidades inteligentes; estudos decoloniais; \\ desobediências epistemológicas; epistemologias do Sul
}

Cidades inteligentes têm sido alvo de indefinições conceituais propositais. Assim como outros termos, como sustentabilidade, ou globalização, smart cities servem a tantos propósitos, sobretudo no campo da venda da tecno-utopia, que tanto mercado quanto academia praticamente esforçam-se para não chegar a um consenso. O objetivo da revisão bibliográfica proposta para dar início a esta

Curso

Doutorado

\section{Linha de Pesquisa}

Design: Processos e Linguagens

\section{Andre Deak Alonso}

André Deak é doutorando em Design na FAU USP. Diretor do Liquid Media Lab, produtor de jornalismo multimídia, consultor de comunicação digital, professor na graduação da ESPM, pesquisador do Laboratório para Outros Urbanismos e do LabCidade da FAU USP. Trabalha desde 1998 com projetos para jornalismo e comunicação na internet. e-mail: andredeak@usp.br Lattes: http://lattes.cnpq. br/0434558072616306

Orcid: https://orcid.org/00000002-1191-4081

\section{Giselle Beiguelman}

Professora Associada nos cursos de Arquitetura e Urbanismo e Design da Universidade de São Paulo. É artista e suas pesquisas abordam: intervenções artísticas com mídias digitais no espaço público; preservação de arte digital; arte e ativismo em rede; estéticas da memória no século XXI.

e-mail: gbeiguelman@usp.br Lattes: http://lattes.cnpq. br/4120752125995822

Orcid: https://orcid.org/00000003-4812-5972 pesquisa foi realizar uma busca sistemática do termo durante artigos publicados no período entre 2008 e 2018 . A busca foi realizada pelo método de raspagem de dados em bases científicas e no Google Scholar, mais amplo. Partimos também do pressuposto conceitual de que faríamos uma leitura do resultado a partir de epistemologias do Sul (BOAVENTURA, 2018), mas também especialmente de um olhar que se pretende decolonial (SANTOS, 2020). Milhares de artigos foram analisados, para chegar finalmente em 1.260 citados mais de 10 vezes em outras pesquisas, e 15 que foram citados mais de 500 vezes, entre os quais oito, apenas, foram citados mais de mil vezes. Estes 15, ou oito textos, formam a base conceitual sobre a qual as cidades inteligentes têm sido erigidas. Houve ainda uma forma complementar de revisão bibliográfica, narrativa, que trouxe outros elementos críticos e auxiliaram na leitura a contrapelo do material resultante dos filtros da raspagem de dados. Percebemos, inclusive, que o próprio método de mineração de dados assemelha-se, afinal, a métodos coloniais de extração de riquezas, não necessariamente condizentes com as melhores formas de produzir conhecimento de formas decoloniais. Os artigos analisados também falham em trazer uma visão aquém da tecno-utopia, da tecnologia como fato evolutivo das cidades, natural, e não uma opção política que pode gerar mais ou menos desigualdades a depender de decisões técnicas-políticas (MOROZOV, BRIA, 2019), porque, afinal, qualquer decisão técnica também é política (FLUSSER, 2002). 


\title{
Smart cities, smart cities: a systematic bibliographic review
}

André Deak Alonso, Giselle Beiguelman

\author{
smart cities; smart cities; decolonial studies; epistemological \\ disobediences; epistemologies of the South
}

Smart cities have been the target of intentional conceptual ambiguity. Like other terms, such as sustainability or globalization, smart cities serve for so many purposes, especially in the context of selling the techno-utopia, that both market participants and academics almost expect not to reach consensus. The purpose of the initial bibliographic review of this research was to perform a systematic search of the relevant articles considering publications between 2008 and 2018. The search was conducted with the application of the method of data scraping, from scientific bases and from Google Scholar. We also considered the conceptual assumption that we would expect to obtain mainly results from South epistemologies (BOAVENTURA, 2018), but also especially from a perspective that is supposed to be decoloniality (SANTOS, 2020).

Course

Doctoral

\section{Line of Research}

Design: Processes and Languages

\section{André Deak Alonso}

$\mathrm{PhD}$ student in Design at FAU USP. Director of Liquid Media Lab, producer of multimedia journalism, digital communication consultant, undergraduate professor at ESPM, researcher at the Laboratory for Other Urbanism and FAC LabCidade. He has been working since 1998 with projects for journalism and internet communication.

e-mail: andredeak@usp.br Lattes: http://lattes.cnpq. br/0434558072616306

Orcid: https://orcid.org/0000-

0002-1191-4081

\section{Giselle Beiguelman}

Associate Professor of Architecture and Urbanism and Design at the University of São Paulo. She is an artist and her research interests include: artistic interventions in the public space with digital media; preservation of digital art; art and activism in the network; 21st century aesthetic memory.

e-mail: gbeiguelman@usp.br

Lattes: http://lattes.cnpq. $\mathrm{br} / 4120752125995822$

Orcid: https://orcid.org/00000003-4812-5972
Thousands of articles were analyzed, obtaining a final sample of 1,260 papers cited more than 10 times in other publications, and 15 papers that were cited more than 500 times, among which only eight were cited more than a thousand times. These 15, or eight texts, form the conceptual basis on which smart cities foundations have been built. There was also a complementary form of bibliographic review, a narrative, which provided other critical elements and helped in a critical reading considering the material that resulted from the scraping filters. We even realized that the data mining method itself is, after all, similar to colonial methods of extracting wealth, not necessarily consistent with the best ways of producing knowledge of decolonial forms. The analyzed articles also fail to bring a vision that falls short of techno-utopia, of technology as an evolutionary fact of cities, natural, and not a political option that can generate more or less inequalities depending on technical-political decisions (MOROZOV, BRIA, 2019 ), because, after all, any technical decision is also political (FLUSSER, 2002).

\section{Referências | References}

BRATTON, B. 2015. The Stack: on software and sovereignty. Cambridge: MIT Press. 